Website: https://journal.stiba.ac.id

ISSN : 2685-7537 (online); 2338-5251 (Printed)

\title{
MASKULINITAS DAN FEMINITAS DALAM AL-QUR'AN (IMPLIKASI SOSIAL ATAS KARAKTER NEGATIF)
}

\section{MASCULINITY AND FEMININITY IN THE QUR'AN (SOCIAL IMPLICATION OF NEGATIVE CHARACTER)}

\author{
Ulvah Nur'aeni \\ Sekolah Pascasarjana UIN Syarif Hidayatullah Jakarta \\ Jl. Kertamukti, No. 5, Pisangan Barat,Cireundeu, Ciputat Timur, Tanggerang Selatan, Banten. \\ Email: urafameteora@gmail.com
}

\author{
Keywords : \\ Al-Qur'an, Masculinity, \\ Femininity, Negative, Social \\ Implication
} \begin{abstract}
This paper presents an argument that the negative feminine and masculine characters possessed by every human being harm social aspects. This argument was obtained because there was a paradigm shift from a traditionalist view to a new concept that was born in the 1970s. The traditionalist paradigm explicates that masculine and feminine characters are seen as contradicting the dimensions of the character's personality, attractiveness, and roles that differentiate men and women. On the other hand, a concept that was born starting in the 1970s emphasized the opposite. For instance, Alfred B. Heilburn categorized masculine and feminine characters as having positive and negative sides. It was also upheld by Sachiko Murata who exposed that both masculine and feminine characters exist in every human being and both have good and bad characters that are not limited to men and women. Uniquely, masculine and feminine concepts, as well as positive and negative characters, are also contained in the Qur'an. Therefore, the Qur'an frees humans to choose masculine or feminine characters as well as positive or negative characters to represent their personality. After tracing verses in the Qur'an about masculine and feminine, both positive and negative, the researcher found that masculine and feminine characters that were considered negative have detrimental implications for personal and social life. Based on this description, the paper tries to examine and explore these social impacts by using the thematic method of the Qur'an and analyzed by the theory proposed by Sachiko Murata.

\section{ABSTRAK}

Kata kunci :

Al-Qur'an, Maskulinitas, Feminintas, Negatif, Implikasi Sosial
Tulisan ini menyampaikan sebuah argumen bahwa karakter negatif feminin dan maskulin yang dimiliki oleh setiap manusia berdampak buruk pada aspek sosial. Argumen ini diperoleh karena ada pergeseran paradigma dari pandangan tradisionalis kepada konsep baru yang lahir pada tahun 1970-an. Paradigma tradisionalis memandang bahwa karakter maskulin dan feminin dipandang kontradiktif dalam dimensi kepribadian karakter, daya tarik, dan peran yang membedakan laki-laki dan perempuan. Sebaliknya, konsep yang lahir dimulai pada tahun 1970-an menegaskan hal yang berkebalikan. Misalnya, Alfred B. Heilburn mengategorikan bahwa karakter maskulin dan feminin memiliki sisi positif dan negatif. Dipertegas pula oleh Sachiko Murata yang berpendapat bahwa baik karakter maskulin maupun feminin ada pada setiap manusia dan keduanya memiliki karakter baik dan buruk yang tidak terbatas pada laki-laki dan perempuan. Uniknya, konsep maskulin 
dan feminin serta karakter positif dan negatif juga terkandung dalam AlQur'an. Oleh karena itu, Al-Qur'an membebaskan manusia untuk memilih karakter maskulin atau feminin serta positif atau negatif untuk merepresentasikan kualitas kepribadiannya. Setelah menelusuri ayatayat Al-Qur'an tentang maskulin dan feminin baik positif maupun negatif, penulis menemukan bahwa karakter maskulin dan feminin yang dianggap negatif memiliki implikasi yang merugikan terhadap kehidupan pribadi serta kehidupan sosial yang lebih luas. Berdasarkan uraian ini, maka tulisan ini mencoba mengkaji dan menggali dampak sosial tersebut dengan menggunakan metode tematik Al-Qur'an dan dianalisis dengan teori yang digagas oleh Sachiko Murata.

Diterima: 31 Oktober 2020; Direvisi: 29 November 2020; Disetujui: 29 November 2020; Tersedia online: 18 Desember 2020.

How to cite : Nur'aeni, U. (2020). Maskulinitas dan Feminitas dalam Al'Qur'an (Implikasi Sosial Atas Karakter Negatif). NUKHBATUL 'ULUM: Jurnal Bidang Kajian Islam, 6 (2), 310-328. https://doi.org/10.36701/nukhbah.v6i2.270

\section{PENDAHULUAN}

Di penghujung abad 20, tepatnya tahun 1960-1970, gerakan feminisme di Barat banyak dipengaruhi oleh filsafat eksistensialime. Jean Paul Satre (w. 1980) adalah tokoh yang mengembangkan teori ini, dan berpendapat bahwa manusia tidak memiliki esensi atau sifat alamiah, karena sifat alamiah terbentuk oleh lingkungannya. Teori tersebut kemudian dilanjutkan oleh Simone de Beavoir (w. 1986) yang berpandangan bahwa sifat-sifat feminin yang menunjukkan pengasuhan, pemeliharaan, merupakan sifat yang dibentuk oleh budaya patriarki ${ }^{1}$.

Bagi peneliti lain yang berbeda pandangan dengan filsafat eksistensialisme, seperti Rhoda K. Unger (w. 2019), ia menyatakan bahwa perbedaan karakter laki-laki dan perempuan disebabkan oleh anatomi biologis dan unsur kimia yang terdapat dalam diri mereka, sehingga hasil dari penelitiannya menunjukkan bahwa karakter laki-laki bernilai positif dan karakter perempuan bernilai negatif ${ }^{2}$. Sedangkan pengkaji lainnya seperti Alfred B. Heilbrun $^{3}$, Janet T. Spence, Robert Helmreich, Joy Stapp ${ }^{4}$ dan Sandra L. Bem ${ }^{5}$

\footnotetext{
${ }^{1}$ Abad 1960-1970 merupakan masa peralihan dari periode pertama yang diungkapkan oleh Hoffman menuju periode kedua yang mengalami perubahan konsep maskulinitas dan feminitas. Lihat Sachiko Murata, The Tao of Islam; A Sourcebook on Gender Relationship in Islamic Thought,terj. Rahmani Astuti dan M.S Nasrullah, (Bandung: Mizan, 1992), h. 7.

${ }^{2}$ Rhoda K. Unger, Female and Male; Psychological Perspectives, (New York: t.p: 1979), h. 30 .

${ }^{3}$ Alfred B. Heilbrun, Jr, "Measurement of Masculine and Feminine Sex Role Identities as Independent Dimensions," Journal of Consulting and Clinical Psychology 44, no. 2 (1976): h. 183.

${ }^{4}$ Janet T. Spence, Robert Helmreich dan Joy Stapp, "Rating of Self and Peers on Sex Role Attributes and Their Relation to Self-Esteem and Conceptions of Masculinity and Femininity," Journal of Personality and Sosial Psychology 32, no. 1 (1975): h.29.
} 
tampaknya lebih mengembangkan teori filsafat eksistensialisme. Kajian mereka mencoba menghilangkan stereotip gender antara laki-laki dan perempuan yang dianggap terpisah dalam setiap individu. Kedua pandangan tersebut meskipun berbeda, namun memiliki kesamaan bahwa penelitian mereka dihasilkan dari beberapa pengujian atau tes yang dilakukan kepada individu atau komunitas manusia $^{6}$.

Kajian Sachiko Murata tampaknya sangat kontras dibanding para pengkaji lainnya. Sachiko Murata melihat aspek maskulinitas dan feminitas dari perspektif teologi Islam. Ia berhasil memunculkan konsep Taoisme ${ }^{7}$ yang menurutnya ada kesamaan dengan konsep Islam. Konsep Taoisme yang dimaksud adalah ajaran mengenai yin dan yang di mana keduanya merupakan hubungan yang saling melengkapi. Menurutnya karakter yin identik dengan keindahan (jamāl), sedangkan yang identik dengan keagungan $(j a l \bar{a} l)^{8}$.

Hal menarik lainnya dari pemikiran Sachiko Murata bahwa pada tataran manusia, maskulinitas dan feminitas memiliki sisi positif dan negatif. Baginya kedua sisi ini perlu adanya keseimbangan sehingga manusia dapat memenuhi amanat yang diembannya sebagai khalifah di bumi ${ }^{9}$. Olek karena itu, jika karakter negatif yang mendominasi, maka kerusakan di muka bumi berpeluang besar terjadi.

Pemikiran Murata tersebut memunculkan inspirasi bagi banyak peneliti. Salah satunya Nur Arfiyah Febriani yang meneliti tentang kerusakan alam dan

${ }^{5}$ Sandra L. Bem, "The Measurement of Psychological Androgyny", Journal of Consulting and Clinical Psychology 42, no. 2 (1974): h. 155.

${ }^{6}$ Tes untuk melakukan penelitian ini diantaranya menggunakan Adjective Check List, Personal Attributes Questionnaire (PAQ), dan lain-lainnya.

${ }^{7}$ Taoisme mulai muncul di awal abad $500 \mathrm{M}$. ada beberapa pandangan mengenai Taosime ini dalam konteks agama di China. Ada yang menyatakan bahwa Taoisme adalah paham oposisi atas ajaran Konghucu dan Budha. Pendapat lain seperti Max Weber melihat bahwa Taoisme justru dikategorikan sebagai Konghucu ortodox. Adapula yang menyatakan bahwa Taoisme tidak akan pernah mejadi agama yang terorganisir. Ia beragam, cair dan tidak ada batasan jelas apakah ia ortodox atau ortopax. Dalam budaya modern, Taosime dipercaya sebagai seperangkat gagasan tertentu. Lihat Max Weber, The Religion of China; Confucianism and Taoism (Illinois: The Free Press, 1951), h. 180. Lihat juga Russell Kirkland, "The History of Taoism: A New Outline", Journal of Chinese Religion 30, no. 1 (2002):h. 180.

${ }^{8}$ Sachiko Murata menjelaskan bahwa hubungan Tuhan dengan manusia diibaratkan hubungan yin dan yang. Keterhubungan ini berasal dari ketidakterbandingan dan keserupaan yang melekat dalam hubungan tersebut. Dijelaskan olehnya bahwa yang tidak tergantung kepada kosmos, sedangkan yin menyerahkan dan bergantung kepada yang. Oleh karenanya, dalam pandangan Sachiko Murata yang identik dengan jalāl karena keagungan Allah tidak dapat terbandingkan oleh kosmos. Sementara yin identik dengan jamāl karena sifat keindahan dapat menjadi teladan bagi hamba-Nya. Sachiko Murata, The Tao of Islam; A Sourcebook on Gender Relationship in Islamic Thought, terj. Rahmani Astuti dan M.S Nasrullah (Bandung: Mizan, 1992), h. 84-86.

${ }^{9}$ Sachiko Murata, The Tao of Islam; A Sourcebook on Gender Relationship in Islamic Thought, terj. Rahmani Astuti dan M.S Nasrullah (Bandung: Mizan, 1992), h. 85. 
relasi gender dalam Al-Qur'an. Baginya kerusakan alam disebabkan oleh karakter maskulin maupun feminin, bukan karakter maskulin saja seperti yang dikembangkan oleh ecofeminism ${ }^{10}$. Namun, berdasarkan penelusuran penulis terhadap beberapa ayat yang berkaitan dengan maskulinitas dan feminitas dalam Al-Qur'an, ketidakseimbangan karakter maskulin dan feminin tidak hanya berimplikasi pada kerusakan alam saja, akan tetapi bisa merambat pada aspek sosial.

Pada titik inilah relevansi penulis untuk mengkaji dan menggali lebih dalam mengenai implikasi ketidakseimbangan karakter maskulin dan feminin tersebut. Untuk itu, masalah yang dijawab dalam tulisan ini adalah berkenaan dengan implikasi atau kerusakan yang diakibatkan karakter maskulin maupun feminin negatif dalam Al-Qur'an.

Pada upaya membuktikan implikasi di atas, maka tulisan ini menggunakan metode tematik dan teori yang dikembangkan oleh Sachiko Murata. Metode tematik diperlukan untuk menghimpun ayat-ayat mengenai karakter maskulin dan feminin baik yang positif maupun negatif. Selanjutnya menggunakan teori Murata mengenai keseimbangan karakter maskulin dan feminin positif. Teori tersebut menjelaskan bahwa dengan adanya keseimbangan karakter positif, maka wujud keindahan dan keagungan Allah dapat terpancar dalam diri manusia sehingga menjadikan manusia layak menjadi khalifah di muka bumi ${ }^{11}$. Dengan demikian, jika keseimbangan itu tidak terjadi maka wujud dari kebalikannya yang akan muncul pada diri seseorang sehingga berdampak pada kehidupan sosial.

\section{PEMBAHASAN}

\section{Maskulinitas dan Femininitas dalam Kerangka Keilmuan Barat}

Kajian maskulinitas dan feminitas ${ }^{12}$ masuk dalam ranah kajian psikologi pada abad $20^{13}$. Rose Marie Hoffman membagi abad ini dalam dua kategori

\footnotetext{
${ }^{10}$ Nur Arfiyah Febriani, Ekologi Berwawasan Gender dalam Perspektif Al-Qur'an," (Bandung: Mizan Pustaka, 2014). Ecofeminism merupakan sebuah gerakan feminist yang muncul pada 1974 untuk menyuarakan persoalan lingkungan hidup secara global. Gerakan ini memandang bahwa sistem patriarkal dan kekuatan kaum laki-laki bertanggung jawab penuh atas kerusakan lingkungan dan laju polusi yang mengiringi manusia, serta mewarisi planet yang tidak dapat dihuni bagi generasi-generasi selanjutnya. Lihat Nancy R. Howell, "Ecofeminism: What One Needs to Know", Zygon 32, no. 2 (1997): h. 231-232.

${ }^{11}$ Sachiko Murata, The Tao of Islam; A Sourcebook on Gender Relationship in Islamic Thought, terj. Rahmani Astuti dan M.S Nasrullah (Bandung: Mizan, 1992), h. 85.

${ }^{12}$ Gill mendefinisikan maskulinitas: "concern with the attainment of goals external to the interaction process", dan feminitas dengan "centers on relational personality traits, such as understanding, caring, nurturance, responsibility, considerateness, and sensitivity”. Lihat Kay M. Palan, Charles S. Areni, Pamela Kiecker, "Reexamining Masculinity, Femininity, and Gender Identity Scales," Marketing Letters 10, no. 4, (November 1999): h. 365. Lihat juga Carrie Paechter, "Masculine Femininities/Feminine Masculinities: Power, Identities and Gender,"
} 
berdasarkan perkembangan kajiannya, yaitu dari tahun 1920-1970 dan dari 1970 hingga tahun 2000. Periode 1920-1970 konsep karakter maskulin dan feminin merupakan karakter yang terpisah dan tidak berhubungan satu sama lain dalam setiap individu. Sedangkan di periode setelahnya terdapat perluasan objek konsep tersebut $^{14}$. Di periode 1970 hingga 2000, fenomena androgini menjadi perhatian. Sandra L. Bem berpendapat bahwa banyak individu yang memungkinkan androgini yaitu memiliki karakter maskulin dan feminin dalam satu individu tergantung situasi yang dihadapi ${ }^{15}$.

Menurut pandangan tradisional, maskulinitas dan feminitas dipandang sebagai sesuatu yang berlawanan dalam dimensi karakter personal, ketertarikan, dan peran-peran yang membedakan laki-laki dan perempuan ${ }^{16}$. Pandangan ini banyak terjadi di kalangan masyarakat tradisional, di mana laki-laki seharusnya memiliki karakter maskulin dan demikian juga perempuan dengan karakter femininnya. Bahkan, di masa ini perbedaan maskulin dan feminin dikaitkan dengan perbedaan secara biologis yang mempengaruhi pada karakter, kualitas dan potensi laki-laki dan perempuan. Hasil dari perbedaan secara biologis ini tidak jarang justru menyudutkan perempuan sebagai kaum kelas dua, di mana karakter maskulin lebih unggul dibandingkan karakter feminin ${ }^{17}$. Misalnya hasil penelitian Rhoda K. Unger yang mengidentifikasi karakter maskulin dan feminin:

Tabel 1. Karakter Maskulin dan Feminin Menurut Rhoda K. Unger.

No Laki-laki (Maskulin) Perempuan (Feminin)

1 Sangat agresif Tidak terlalu agresif

Gender Education, h. 257 dan lihat Stephen Frosh, Sexual Difference: Masculinity and Psychoanalysis, (New York: Taylor \& Francis e-Library, 2002), h. 3-4. Merespon pandangan Gill di atas, penulis memandang bahwa baik maskulinitas maupun femininitas adalah karakter yang dimiliki oleh setiap orang baik laki-laki maupun wanita. Pandangan ini tentu berbeda dengan ekofeminisme yang menunjukkan bahwa karakter maskulin hanya dimiliki oleh kaum laki-laki, sedangkan feminin hanya dimiliki oleh kaum wanita.

${ }^{13}$ J G Morawski, "The Measurement of Masculinity and Femininity: Engendering Categorical Realities", (Durham: Duke University, 1985), h. 108.

${ }^{14}$ Rose Marie Hoffman, "Measurement of Masculiniy and Femininity: Historical Perpective and Implication for Counseling", Journal of Counseling and Development 79, (2001): h. 472-476.

${ }^{15}$ Sandra L. Bem, "The Measurement of Psychological Androgyny", Journal of Consulting and Clinical Psychology 42, no. 2 (1974): h. 155.

${ }^{16}$ Menurut Jacob L. Orlofsky dan Jayne E. Stake, pandangan ini sebenarnya bisa dilihat sebagai sebuah kesatuan yang terangkum dari perbedaan karakter, minat dan prilaku maskulin maupun feminin. Lihat Jacob L. Orlofsky dan Jayne E. Stake, "Psychological Masculinity and Femininity: Relationship to Striving and Self-Concept in The Achievemen and Interpersonal Domains" Psychology of Women Quarterly 6, (1981): h. 218, Lihat juga Rose Marie Hoffman, "Measurement of Masculiniy and Femininity: Historical Perpective and Implication for Counseling", Journal of Counseling and Development 79, (2001): h. 472.

${ }^{17}$ Dikutip dari Nur Arfiyah Febriani, Ekologi Berwawasan Gender dalam Perspektif AlQur'an," (Bandung: Mizan Pustaka, 2014), h. 145. 


\begin{tabular}{|c|c|c|}
\hline 2 & Independen & Tidak terlalu independen \\
\hline 3 & Emosional & Lebih emosional \\
\hline 4 & Dapat menyembunyikan emosi & Sulit menyembunyikan emosi \\
\hline 5 & Lebih objektif & Lebih subjektif \\
\hline 6 & Tidak mudah terpengaruh & Mudah terpengaruh \\
\hline 7 & Tidak submisif & Lebih submisif \\
\hline 8 & Sangat menyukai pengetahuan eksakta & Kurang menyukai eksakta \\
\hline 9 & Tidak mudah goyah terhadap krisis & Mudah goyah dalam krisis \\
\hline 10 & Lebih aktif & Lebih pasif \\
\hline 11 & Lebih kompetitif & Kurang kompetitif \\
\hline 12 & Lebih logis & Kurang logis \\
\hline 13 & Lebih mendunia & Berorientasi ke wilayah domestik \\
\hline 14 & Lebih terampil berbisnis & Kurang terampil berbisnis \\
\hline 15 & Lebih terus terang & Kurang terus terang \\
\hline 16 & $\begin{array}{l}\text { Memahami seluk beluk perkembangan } \\
\text { dunia }\end{array}$ & $\begin{array}{l}\text { Kurang memahami } \quad \text { seluk } \\
\text { perkembangan dunia }\end{array}$ \\
\hline 17 & Tidak mudah tersinggung & Berperasaan mudah tersinggung \\
\hline 18 & Lebih suka berpetualang & Tidak suka berpetualang \\
\hline 19 & Mudah mengatasi persoalan & Sulit mengatasi persoalan \\
\hline 20 & Jarang menangis & Lebih sering menangis \\
\hline 21 & Umumnya menjadi pemimpin & Tidak umum sebagai pemimpin \\
\hline 22 & Penuh rasa percaya diri & Kurang percaya diri \\
\hline 23 & Lebih banyak mendukung sikap agresif & Kurang senang sikap agresif \\
\hline 24 & Lebih ambisi & Kurang ambisi \\
\hline 25 & $\begin{array}{l}\text { Lebih mudah membedakan antara rasa } \\
\text { dan rasio }\end{array}$ & Sulit membedakan antara rasa dan rasio \\
\hline 26 & Lebih merdeka & Kurang merdeka \\
\hline 27 & Tidak canggung dalam penampilan & Lebih canggung dalam penampilan \\
\hline 28 & Pemikiran lebih unggul & Pemikiran kurang unggul \\
\hline 29 & Lebih bebas berbicara & Kurang bebas berbicara \\
\hline
\end{tabular}

Namun, karena perkembangan masyarakat modern, pandangan tersebut pun digantikan dengan konsep yang baru. Konsep yang menentang pandangan bahwa maskulin dan feminin adalah karakter yang bertentangan ${ }^{18}$. Seperti pendapatnya Jacob L. Orlofsky, Jayne E. Stake dan Alfred B. Heilbrun, pandangan baru ini melihat karakter maskulin dan feminin sebagai dimensi yang independen dalam pengertian bahwa kedua karakter ini ada dalam diri setiap individu ${ }^{19}$.

${ }^{18}$ Pandangan ini berlangsung dari tahun 1920 hingga 1970. Lihat Rose Marie Hoffman, "Measurement of Masculiniy and Femininity: Historical Perpective and Implication for Counseling", Journal of Counseling and Development 79, (2001): h. 472.

${ }^{19}$ Jacob L. Orlofsky dan Jayne E. Stake, "Psychological Masculinity and Femininity: Relationship to Striving and Self-Concept in The Achievemen and Interpersonal Domains", Psychology of Women Quarterly 6, (1981): h. 219, lihat juga Afred B. Heilbrun, Jr, "Measurement of Masculine and Feminine Sex Role Identities as Independent Dimension," 
Pandangan Jacob L. Orlofsky dan Jayne E. Stake memiliki kesamaan dengan pandangan Sandra L. Bem yang menawarkan konsep bahwa maskulinitas dan feminitas adalah sebuah gagasan yang independen. Sandra L. Bem memandang bahwa laki-laki dan perempuan memiliki tingkat karakter dan kemampuan maskulin dan feminin yang bervariasi. Terlebih karakteristik tipe gender ini dapat mempengaruhi perilaku dan meningkatkan aktivitas seseorang ${ }^{20}$. Konsep yang diusulkan Sandra L. Bem kemudian ia perkuat dengan bukti bahwa laki-laki dan perempuan yang menunjukkan kualitas yang tinggi pada karakter maskulin dan feminin mampu menguasai situasi, mandiri, dan memiliki kepekaan terhadap yang lainnya. Sebaliknya, seseorang yang menunjukkan kualitas yang tinggi pada satu karakter saja, hanya mampu mengendalikan situasi yang berhubungan dengan satu karakter itu saja ${ }^{21}$.

Berkaitan dengan karakter maskulin dan feminin, para peneliti telah melakukan kategorisasi dan bahkan mengembangkan kategori kedua karakter tersebut. Sandra L. Bem tidak hanya mengklasifikasikan pada maskulin dan feminin saja, akan tetapi ia mengembangkannya menjadi 4 kategori, yaitu feminin, maskulin, androgini dan netral ${ }^{22}$. Sedangkan Janet T. Spence, Robert Helmreich dan Joy Stapp mengembangkannya menjadi 3 kategori, yaitu maskulin, feminin dan sex spesifik ${ }^{23}$. Berbeda dengan Alfred B. Heilbrun, ia tetap mengklasifikasikannya pada dua karakter saja, yaitu maskulin dan feminin. Penelitian yang dilakukannya dengan menggunakan Adjective Check List

Journal of Consulting and Clinical Psychology 44, no. 2, h. 183. Selain faktor perkembangan masyarakat modern, terdesaknya kondisi suatu masyarakat karena faktor ekonomi yang berkepanjangan seperti yang terjadi di Gaza menyebabkan karakter maskulin dan feminin secara tradisional menjadi berubah. Ibu rumah tangga dan wanita muda berperan juga dalam menghidupi keluarga mereka. Muhanna berpendapat bahwa masuknya perempuan dalam sektor publik di sini tidak menunjukkan adanya emansipasi wanita, karena melumpuhkan wanita muda ketika dipaksa untuk bekerja di luar rumah pada saat intifada ke 2 terjadi. Lihat review atas Aitemahad Muhanna, "Agency and Gender in Gaza: Masculinity and Family during the Second Intifada", Gender \& History 27, no. 1, (April 2015): h. 230.

${ }^{20}$ Dikutip oleh Yingying Yang dan Edward C. Merrill, "Cognitive and Pesonality Characteristics of Masculinity and Femininity Predict Wayfinding Competence and Strategies of Men and Woman," Sex Roles.

${ }^{21}$ Jacob L. Orlofsky dan Jayne E. Stake, "Psychological Masculinity and Femininity: Relationship to Striving and Self-Concept in The Achievemen and Interpersonal Domains," Psychology of Women Quarterly 6, (1981): h. 219.

${ }^{22}$ Anna Herman Jeglińska, Anna Grabowska, dan Stanislaw Dulko, "Masculinity, Femininity, and Transsexualism," Archives of Sexsual Behavior 3, no. 6, (Desember 2002): h. 529.

${ }^{23}$ Hasil ini didapatkan berdasarkan penelitian dengan menggunakan Personal Attributes Questionaire terhadap komunitas mahasiswa. Pada penelitian ini, subjek diminta untuk menilai diri mereka sendiri dari serangkaian sifat dan ciri-ciri pada laki-laki dan perempuan. Baca lebih lanjut Janet T. Spence, Robert Helmreich dan Joy Stapp, "Rating of Self and Peers on Sex Role Attributes and Their Relation to Self-Esteem and Conceptions of Masculinity and Femininity," Journal of Personality and Sosial Psychology 32, no. 1, (1975): h. 29-30. 
memberikan gambaran dan karakter-karakter maskulin dan feminin seperti di bawah ini: ${ }^{24}$

Tabel 2. Karakter Maskuln dan Feminis Menurut Alfred B. Heilbrun.

\begin{tabular}{|c|c|c|}
\hline No & Maskulin & Feminin \\
\hline 1 & Agresif & Menghargai \\
\hline 2 & Sombong & Penuh perhatian \\
\hline 3 & Tegas & Menantang \\
\hline 4 & Angkuh & Bergant ung \\
\hline 5 & Percaya diri & Emosional \\
\hline 6 & Suka memperolok-olok & Menggugah \\
\hline 7 & Tergesa-gesa & Penakut \\
\hline 8 & Dominan/berkuasa & Bersifat kewanitaan \\
\hline 9 & Giat & Ragu-ragu \\
\hline 10 & Pemimpin & Memaafkan \\
\hline 11 & Berorientasi ke depan & Ramah \\
\hline 12 & Terus terang & Tidak karuan \\
\hline 13 & Gagah & Suka menolong \\
\hline 14 & Keras kepala & Ceria \\
\hline 15 & Tekun & Rendah hati \\
\hline 16 & Berbakat & Suka memuji \\
\hline 17 & Senang berkarya & Peka \\
\hline 18 & Kelaki-lakian & Sentimentil \\
\hline 19 & Oportunis & Tulus \\
\hline 20 & Cerdas & Patuh \\
\hline 21 & Kuat & Suka bersimpati \\
\hline 22 & Keras & Malu-malu \\
\hline 23 & Ingin balas dendam & Mudah khawatir \\
\hline
\end{tabular}

\section{Maskulinitas dan Femininitas dalam Kerangka Keilmuan Islam}

Berdasarkan karakter-karakter maskulin dan feminin yang digambarkan oleh Alfred B. Heilbrun, dapat dilihat bahwa terdapat karakter negatif dan positif tampak pada karakter maskulin dan feminin ${ }^{25}$. Uniknya, konsep maskulin dan

${ }^{24}$ Alfred B. Heilbrun, Jr, "Measurement of Masculine and Feminine Sex Role Identities as Independent Dimensions," Journal of Consulting and Clinical Psychology 44, no. 2, (1976): h. 183-184.

${ }^{25}$ Penelitian mengenai karakter maskulin dan feminin dalam satu dimensi atau dengan istilah yang dipakai oleh Spence, Helmreich dan Holahan "meniru-niru karakter" membuahkan hasil yang menarik. Laki-laki dianggap lebih unggul dari perempuan pada karakter yang mencerminkan kecakapan pribadi dan orientasi pada tujuan. Sedangkan perempuan dianggap paling unggul pada sifat yang menunjukkan kepekaan emosi sosial dan orientasi pada hubungan interpersonal. Baca lebih lanjut dalam Janet T. Spence, Robert L. Helmreich dan Carole K. Holahan, "Negative and Positive Components of Psychological Masculinity and Femininity and Their Relationships to Self-Reports of Neurotic and Acting Out Behaviors," Journal of Personality and Social Psychology 37, no. 10, (1979). 
feminin serta karakter positif maupun negatif tersebut pun terdapat dalam AlQur'an ${ }^{26}$. Sachiko Murata berpendapat bahwa baik karakter maskulin maupun feminin ada dalam diri setiap manusia dan keduanya memiliki karakter baik dan buruk. Di sisi lain, Al-Qur'an sebagai sumber ajaran Islam dan pedoman bagi Muslim memberikan tawaran dan keleluasan kepada umat Islam untuk menentukan karakter maskulin maupun feminin yang dapat meneguhkan jati dirinya. Manusia dapat memilih karakter sesuai yang diinginkannya dan kemudian akan dimintai pertanggungjawabannya di akhirat kelak ${ }^{27}$.

Meskipun demikian, terdapat pula pandangan dari sebagian ulama yang cenderung memposisikan laki-laki lebih unggul dibanding perempuan, atau dengan kata lain karakter maskulin lebih unggul dari karakter feminin. Pandangan tersebut diperparah dengan melegitimasi ayat Al-Qur'an. Ayat AlQur'an yang biasa digunakan untuk menunjukkan superioritas maskulin adalah surat al-Nisā/4: 34,

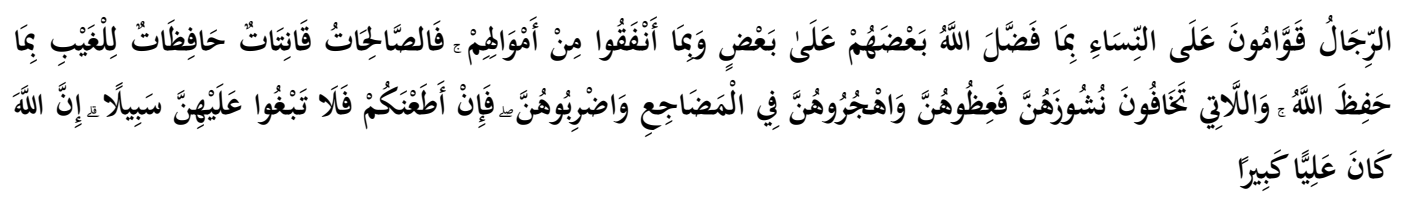

Terjemahnya:

“Kaum laki-laki itu adalah pemimpin bagi kaum wanita, oleh karena Allah telah melebihkan sebahagian mereka (laki-laki) atas sebahagian yang lain (wanita), dan karena mereka (laki-laki) telah menafkahkan sebagian dari harta mereka. sebab itu Maka wanita yang saleh, ialah yang taat kepada Allah lagi memelihara diri ketika suaminya tidak ada, oleh karena Allah telah memelihara (mereka). wanita-wanita yang kamu khawatirkan nusyuznya, Maka nasehatilah mereka dan pisahkanlah mereka di tempat tidur mereka, dan pukullah mereka. kemudian jika mereka mentaatimu, Maka janganlah kamu mencari-cari jalan untuk menyusahkannya. Sesungguhnya Allah Maha Tinggi lagi Maha besar."

Ayat tersebut seringkali dijadikan sebagai alat untuk menundukkan kaum perempuan. Di antara pandangan yang menyudutkan itu adalah mengenai keunggulan kepemimpinan laki-laki, karena ayat tersebut menyebutkan bahwa laki-laki adalah qawwam (pemimpin) perempuan. Kemudian perempuan harus mematuhi suaminya agar disebut muslimah yang salihah, selain itu suami berhak memukul istrinya untuk menghindari pembangkangan, dan jika seorang istri

${ }^{26}$ Mengenai hal ini, pada sub bab selanjutnya dibahas ayat-ayat mana saja yang tergolong maskulin dan feminin.

${ }^{27}$ Mengenai hal ini penulis merujuk dan setuju dengan pendapat Nur Arfiyah Febriani dalam Nur Arfiyah Febriani, Ekologi Berwawasan Gender dalam Perspektif Al-Qur'an," (Bandung: Mizan Pustaka, 2014), h. 163-167. 
tidak menerima penundukan tersebut, seorang suami berhak menceraikan istrinya ${ }^{28}$.

Pandangan dan pemahaman yang setengah-setengah terhadap ayat di atas dan mengabaikan adanya kewajiban suami terhadap seorang istri menjadikan perempuan sebagai warga kelas dua dan merendahkan peran, karakter serta kualitas perempuan ${ }^{29}$. Bahkan di beberapa kasus, interpretasi yang keliru mengakibatkan terjadinya Kekerasan Dalam Rumah Tangga (KDRT) ${ }^{30}$.

Kualitas akal perempuan pun menjadi sasaran pandangan yang menomorduakan karakter feminin. Sebagian ulama berpandangan bahwa akal perempuan adalah setengah dari akal laki-laki. Pandangan tersebut salah satunya berasal dari pemahaman atas ayat Al-Qur'an pada surat al-Baqarah/2: 282,

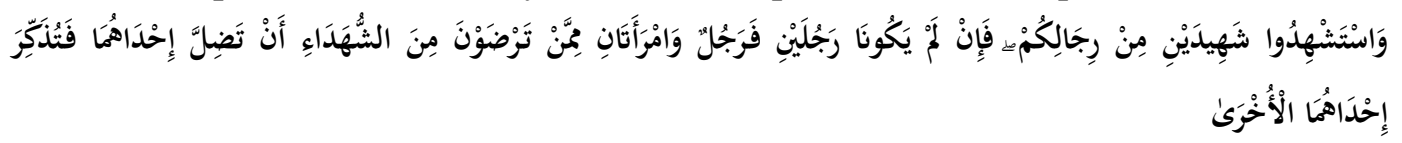

Terjemahnya:

"Dan persaksikanlah dengan dua orang saksi dari orang-orang lelaki (di antaramu). jika tak ada dua oang lelaki, Maka (boleh) seorang lelaki dan dua orang perempuan dari saksi-saksi yang kamu ridai, supaya jika seorang lupa Maka yang seorang mengingatkannya."

Al-Zamakhsyarī (w. 1144M) ${ }^{31}$ dan al-Rāzī (w. 925M) ${ }^{32}$ senada dalam mengemukakan bahwa secara inheren, kecerdasan perempuan memanglah lebih lemah dibandingkan laki-laki dan lupa bukanlah sifat bawaan laki-laki. Selain surat al-Baqarah ayat 282, hadis mengenai persaksian pun turut menjadi dalil andalan ulama yang mengunggulkan karakter maskulin ${ }^{33}$.

\footnotetext{
${ }^{28}$ Kaukab Siddique, Menggugat "Tuhan yang Maskulin”, terj. Arif Maftuhin, (Jakarta: Paramadina, 2002), h. 11

${ }^{29}$ Kaukab Siddique, Menggugat “Tuhan yang Maskulin”, terj. Arif Maftuhin, (Jakarta: Paramadina, 2002), h. 12. Lihat juga Siti Musdah Mulia dan Marzani Anwar. Ed, Keadilan dan Kesetaraan Jender Perpektif Islam, (Tim Pemberdayaan Perempuan Bidang Agama Departemen Agama RI, 2001), h. 69.

${ }^{30}$ Syafiq Hasyim, Ed, "Kekerasan dalam Rumah Tangga: Sebuah Kejahatan yang Tersembunyi" dalam Menakar "Harga" Perempuan; Eksplorasi Lanjut atas Hak-hak Reproduksi Perempuan, (Bandung: Mizan, 1999), h. 192-193. Lihat juga Farha Ciciek, Ikhtiar dalam Mengatasi Kekerasan dalam Rumah Tangga; Belajar dari Kehidupan Rasulullah saw, (Jakarta: Lembaga Kajian Agama dan Gender, 1999), h. 27.

${ }^{31} \mathrm{Al}-Z$ amakhsyari, Tafsìr al-Kasysyāf 'an Haqāiq al-Tanzīl wa 'Uyūn li al-Aqāwīl fì Wujūh al-Ta’wīl, Vol.5 (Beirut: Dār al-Ma'rifah, 2009), h. 234.

${ }^{32}$ Al-Rāzì, Mafătīh al-Gā̄b,Vol. 10 (Beirut: Dār al-Fikr), h. 91.

${ }^{33}$ Hadits yang dimaksud adalah hadits berikut, yang artinya:

“Wahai kaum perempuan! Bersedekahlah kalian dan perbanyaklah istighfar. Karena aku melihat kalian lebih ramai menjadi penghuni neraka." Seorang yang cukup pintar di antara mereka bertanya: "Wahai Rasulullah, kenapa kami kaum perempuan yang lebih ramai menjadi penghuni neraka?" Rasulullah bersabda, "kalian banyak mengutuk dan mengingkari suami. Aku tidak melihat yang kekurangan akal dan agama dari pemiliki pemahaman lebih dari golongan kalian." Perempuan itu bertanya lagi: "Wahai Rasulullah! Apa maksud kekurangan akal dan agama itu?"
} 
Fakta dan interpretasi di atas bertolak belakang dengan fakta sejarah Islam awal di mana perempuan dipandang sama dengan laki-laki yang berpeluang meraih prestasi gemilang. Akan tetapi, fakta tersebut tidak bertahan lama. Hal itu meluruh seiring dengan penyebaran Islam yang pesat ke wilayah-wilayah kerajaan yang bercorak misoginis, seperti Persia, Baghdad, dan Damaskus ${ }^{34}$. Dampaknya, hadis-hadis dipalsukan demi kepentingan politis dan menyentuh pada ranah kedudukan perempuan yang cenderung merendahkan perempuan ${ }^{35}$.

Faktor lainnya adalah konstruksi kitab-kitab keagamaan seperti tafsir, hadis, fikih dipengaruhi oleh budaya patriarki yang membatasi ruang gerak perempuan. Kodrat perempuan dan perannya dianggap sama sehingga perempuan seolah tertutup untuk berkontribusi dalam berbagai bidang kehidupan bermasyarakat ${ }^{36}$. Menanggapi adanya pengunggulan atas satu karakter dan mendiskreditkan karakter lainnya, Nasaruddin Umar berpandangan bahwa agama Islam mengakui adanya perbedaan. Perbedaan tersebut terletak pada aspek biologis yang disebut dengan atribut gender. Namun, perbedaan tersebut bukan dimaksudkan untuk merendahkan atau mengunggulkan salah satu dari perempuan maupun laki-laki ${ }^{37}$. Pandangan yang membedakan laki-laki dan perempuan dari sisi biologis akan berimplikasi pada beban gender dalam menentukan peran sosial-budaya di masyarakat padahal peran di masyarakat tidak harus ditentukan oleh atribut biologis ${ }^{38}$.

\section{Klasifikasi Maskulinitas dan Feminitas dalam Al-Qur'an}

Lebih lanjut Murata memberikan indikator karakter maskulin maupun feminin. Menurutnya karakter maskulin positif yaitu jiwa yang berdamai dengan

Rasulullah menjawab: "Maksud kekurangan akal ialah persaksian dua orang perempuan sama dengan persaksian satu laki-laki. Mereka menjawab: "Betul, wahai Rasulullah." Nabi pun berkata: "itulah yang dimaksud dengan kekurangan akal. Begitu juga perempuan tidak mengerjakan shalat pada malam-malam yang dilaluinya kemudian berbuka pada bulan Ramadhan karena haidh. Maka inilah yang dikatakan kekurangan agama."Hadis ini diriwayatkan oleh Imam Bukhārī dalam Ṣāhịh Bukhān̄, kitab hạaị, bāb: Tark al- hạaị al-Saum, no. 293. Kualitas hadis ini șāhịh. Hadis serupa dapat ditemukan pada Bukhārī, no. 1369, Tirmiżī, no. 2538, Ahmad, no. 5091 .

${ }^{34}$ Mayola Andika, "Reinterpretasi Ayat Gender dalam Memahami Relasi Laki-laki dan Perempuan (Sebuah Kajian Kontekstual dalam Penafsiran)", Musawa 17, no. 2, (Juli 2018): h. 142.

${ }^{35}$ Ariana Suryorini, "Menelaah Feminisme dalam Islam", Sawwa 7,no. 2, (2012): h. 23

${ }^{36}$ Ariana Suryorini, "Menelaah Feminisme dalam Islam", Sawwa 7,no. 2, (2012): h. 23

${ }^{37}$ Nasaruddin Umar membedakan permasalahan gender pada $3 \mathrm{hal}$; yaitu atribut gender, identitas gender dan beban gender. Atribut gender adalah aksesori biologis yang membedakan laki-laki dan perempuan. Sedangkang identitas gender adalah kekhususan yang melekat pada diri laki-laki atau perempuan. Dan nilai serta peran budaya pada laki-laki dan perempuan dinamakan beban gender. Lihat Nasaruddin Umar, Kodrat Perempuan dalam Islam, Jakarta: Lembaga Kajian Agama dan Gender, 1999), h. 7-8.

${ }^{38}$ Nasaruddin Umar, Kodrat Perempuan dalam Islam, (Jakarta: Lembaga Kajian Agama dan Gender, 1999), h. 2. 
Tuhannya dan mampu mengalahkan nafsu amarah. Di antara karakter maskulin positif yang terdapat dalam Al-Qur' an adalah konsisten (Qs.8/45), mendunia (Qs. 17/70; 49/13), kompetitif (Qs. 18/30), aktif (Qs. 4/95; 47/31), adil (Qs. 5/42; 49/9; 60/8), benar (Qs. 14/17; 49/15), logis (Qs. 2/164; 13/4, 16/12; 29/35), independen (Qs. 8/53), dan lain-lain. Sedangkan maskulin negatif adalah sifatsifat yang menyerupai sifat iblis dan menuhankan dirinya. Karakter maskulin negatif di antaranya; sombong (Qs. 7/48; 40/60), eksploitatif (Qs. 2/60; 5/32, 33; 7/56; 26/183; 28/4, 39; ), kikir (Qs. 4/128), banyak membantah (Qs. 18/54; 22/3; 16/4), boros (Qs. 17/26-27), dan lain-lain.

Adapun karakter feminin positif menunjukkan kehambaan, penyerahan dan kepatuhan. Karakter feminin positif di antaranya; taat (Qs. 1/5; 2/21; 8/46), sabar (Qs. 16/42; 46/35; 8/66), tawakal (QS. 8/49, 3/122, 159; 9/129; 10/71; $11 / 56,88 ; 12 / 67 ; 13 / 30$ ), ikhlas (Qs. 2/139; 4/125; 7/29; 39/2), dan sifat lainnya. Sementara feminin negatif adalah yang menyerah pada ketentuan-ketentuan yang lebih rendah/hawa nafsu. Karakter feminin negatif yang termasuk dalam kategori ini adalah lemah (Qs. 4/28), berkeluh kesah (Qs. 7/19-20), cinta harta (Qs. 104/14), berbuat curang terhadap harta (Qs. 83/1-4), menggunjing (Qs. 49/12), dan karakter lainnya ${ }^{39}$.

\section{Karakter Maskulin dan Feminin Negatif dalam Al-Qur'an dan Implikasinya Terhadap Aspek Sosial}

Setelah melakukan penelusuran ayat-ayat Al-Qur'an mengenai maskulin dan feminin baik itu positif maupun negatif, penulis menemukan bahwa karakter maskulin dan feminin yang dinilai negatif memiliki implikasi buruk pada kehidupan pribadi maupun kehidupan sosial yang lebih luas terutama pada persoalan sosial. Salah satu indikasi adanya implikasi negatif ini terdapat dalam surah al-Qașāṣ/28:4, yang berbicara mengenai kesombongan Fir'aun. Sifat maskulin negatif yang dimiliki Fir'aun yaitu kesombongan berdampak pada hancurnya tatanan masyarakat yang seharusnya aman, tentram dan damai.

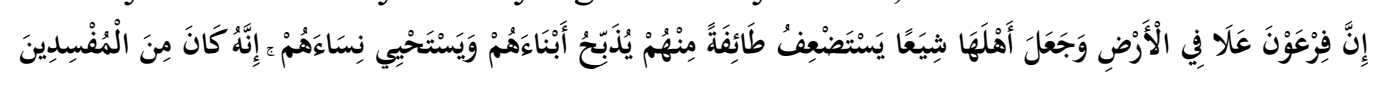

Terjemahnya:

"Sesungguhnya Fir'aun telah berbuat sewenang-wenang di muka bumi dan menjadikan penduduknya berpecah belah, dengan menindas segolongan dari mereka, menyembelih anak laki-laki mereka dan membiarkan hidup anak-anak perempuan mereka. Sesungguhnya Fir'aun termasuk orangorang yang berbuat kerusakan”.

\footnotetext{
${ }^{39}$ Sachiko Murata, The Tao of Islam; A Sourcebook on Gender Relationship in Islamic Thought,terj. Rahmani Astuti dan M.S Nasrullah, (Bandung: Mizan, 1992), h. 350-352. Lihat juga Nur Arfiyah Febriani, Ekologi Berwawasan Gender dalam Perspektif Al-Qur'an," (Bandung: Mizan Pustaka, 2014), h. 168-169.
} 
Dalam ayat tersebut menurut Wahbah al-Zuhaili (w. 2015), karena kesombongan, menuhankan diri dan kekhawatiran akan hilangnya kekuasaannya, ia membunuh anak-anak laki-laki dan membiarkan hidup anak perempuan, melecehkan dan menghina mereka bahkan menyebarkan ketakutan dan teror ${ }^{40}$. Diperjelas oleh M. Quraish Shihab bahwa kerusakan yang diakibatkan oleh keangkuhan penguasa Mesir ini di antaranya; pertama, melahirkan banyak kerusakan; kedua, memecah belah umat yang satu untuk memperkuat kekuasaannya; ketiga, mengancam kehilangan banyak nyawa akibat pembunuhan terhadap orang-orang tak berdosa dan mempermalukan perempuan yang dibiarkan hidup ${ }^{41}$.

Contoh kesombongan lainnya yang dicontohkan dalam Al-Qur'an adalah tokoh Qarun dalam surah al-Qașāṣ/28: 76,

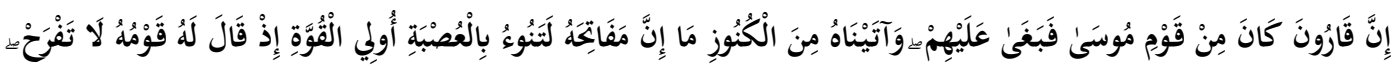

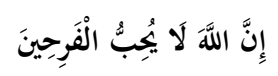

Terjemahnya:

"Sesungguhnya Karun adalah termasuk kaum Musa, maka ia berlaku aniaya terhadap mereka, dan Kami telah menganugerahkan kepadanya perbendaharaan harta yang kunci-kuncinya sungguh berat dipikul oleh sejumlah orang yang kuat-kuat. (ingatlah) ketika kaumnya berkata kepadanya: "Janganlah kamu terlalu bangga; Sesungguhnya Allah tidak menyukai orang-orang yang terlalu membanggakan diri".

Dijelaskan dalam ayat di atas bahwa Qarun memiliki harta yang melimpah hingga barang-barang yang dimilikinya sulit untuk dipikul kecuali oleh sejumlah orang yang kuat. Kekayaannya membuat banyak orang iri dan mendorongnya melakukan tindakan zalim, melampaui batas dan sombong akan hartanya. Kesombongannya ini tampak pada pengakuannya bahwa harta yang dimilikinya dikarenakan ilmu serta hasil dari apa yang telah diusahakannya ${ }^{42}$.

Dampak dari kesombongan Qarun serupa dengan Fir'aun yang mana keduanya dihukum oleh Allah dengan cara ditenggelamkan. Ini menunjukkan bahwa kesombongan adalah sifat yang berdampak besar bagi diri sendiri, masyarakat maupun kerusakan di muka bumi, karena Allah tidak akan

${ }^{40}$ Wahbah al-Zuhaili, al-Tafsīr al-Mun̄ir fì al-'aqūdah al-Syar̄’ah wa al-Manhāj, (Beirut: Dār al-Fikr al-Mu'āṣir, 1998), h. 56-57. Lihat juga Sa'īd Ḥawwā, al-Asās fì al-Tafsìr, (Mesir: Dār al-Salām, 1999), h. 4060.

${ }^{41}$ M. Quraish Shihab, Tafsìr al-Miṣbāh; Pesan, Kesan dan Keserasian Al-Qur'an, (Jakarta: Lentera Hati, 2002), vol. 10, h. 307.

${ }^{42}$ Beberapa tafsir menjelaskan bahwa ilmu yang dimaksud dalam ayat ini adalah ilmu Kimia. Adapula yang mengatakan ilmu perdagangan sehingga ia memperoleh harta yang melimpah. Lihat al-Baghawī, Tafsìr al-Baghaw̄i; Ma'àlim al-Tanzìl, jilid 6 (Riyadh: Dār Ṭayyibah, 1990), h. 222. Lihat juga al-Baiḍāwī, Anwār al-Tanz̄l wa Asrār al-Ta'wīl, jilid 4 (Dār Ihyā al-Turāth al-'Arab̄i), h. 185. 
menghukum hamba-Nya dengan cara seperti demikian jika apa yang dilakukannya merupakan dosa yang ringan. Bagi diri sendiri, kesombongan akan menjadikan pelakunya tidak peka terhadap lingkungan sekitar, tidak pandai bersyukur, serakah, dan pelit. Sementara dampaknya bagi masyarakat yaitu dapat merusak tatanan masyarakat dan adanya kesenjangan sosial. Dampak bagi kerusakan bumi adalah adanya eksploitasi sumber daya alam yang berdampak buruk pada ekosistem di bumi.

Dampak sosial lainnya diakibatkan oleh feminin negatif pada diri seseorang yaitu yang menyerah pada hawa nafsunya. Seperti yang dilakukan oleh Qabil yang direkam dalam surah al-Mā'idah/5: 30,

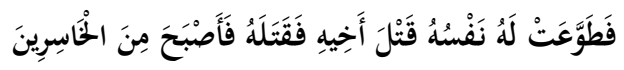

Terjemahnya:

"Maka hawa nafsu Qabil menjadikannya menganggap mudah membunuh saudaranya, sebab itu dibunuhnyalah, maka jadilah ia seorang di antara orang-orang yang merugi".

Dalam menafsirkan ayat di atas, Ibn Kasī̄r (w. 1373 M) mejelaskan bahwa pembunuhan yang dilakukan oleh Qabil dikarenakan nafsunya menganjurkan, menggoda, membujuknya serta menjadikan tindakan pembunuhan sebagai hal yang baik,. ${ }^{43}$ Terlebih M. Quraish Shihab menambahkan bahwa Qabil menyerah terhadap hawa nafsunya bukan tanpa tantangan. Ia dihadapkan dengan pilihan untuk menerima bisikan agar mengurungkan niat membunuh atau memilih untuk taat kepada hawa nafsunya. Hawa nafsunya mendorong sedikit demi sedikit hati dan pikiran Qabil dan pada akhirnya ia membunuh saudaranya. Dengan kata lain, Qabil telah memilih karakter feminin negatif yang merupakan representasi dari jati dirinya sehingga ia disebut-sebut sebagai pelaku pertama pembunuhan di muka bumi. ${ }^{44}$

Pembunuhan dikategorikan sebagai dosa besar karena Al-Qur'an menegaskan bahwa balasan bagi pembunuh adalah neraka ${ }^{45}$. Balasan tersebut mengisyaratkan bahwa ada dampak besar yang timbul karena tindakan pembunuhan dalam kehidupan manusia. Pembunuhan dapat mengganggu ketentraman dan keamanan manusia. Tindakan pembunuhan yang dibiarkan terjadi justru menimbulkan kerusakan di muka bumi dan pertumpahan darah yang lebih besar.

Salah satu contoh pembunuhan yang berdampak pada masyarakat lebih luas lainnya adalah bunuh diri yang dilatarbelakangi oleh kesalahpahaman dalam

${ }^{43} \mathrm{Ibn}$ Kasìī, Tafsīr al-Qur'ān al- 'Adhīm, jilid 3 (Riyadh: Dār Ṭayyibah li al-Nașr wa alTauzi', 1999), h. 88.

${ }^{44}$ M. Quraish Shihab, Tafsīr al-Miṣbāh; Pesan, Kesan dan Keserasian Al-Qur'an, (Jakarta: Lentera Hati, 2002), vol 3, h. 96.

${ }^{45}$ Lihat surah al-Nisā/4: 30 dan 93. 
memaknai jihad. Bunuh diri yang biasa dilakukan oleh para pelaku teroris merupakan tindakan yang dikecam oleh Islam. Ini karena tujuan terorisme berdampak pada kehidupan sosial, yaitu menakut-nakuti dan membuat resah masyarakat, dilakukan tanpa aturan dan sasaran yang mengakibatkan kerugian dan terampasnya harta dan jiwa banyak orang yang tidak bersalah ${ }^{46}$.

Perilaku menyerah pada ketentuan yang lebih rendah lainnya adalah sebagaimana yang dilakukan oleh kaum Nabi Luth as. Dijelaskan dalam surah Hūd/11: 79,

$$
\text { قَالُوا لَقَدْ عَلِمْتَ مَا لَنَا فِي بَنَاتِكَكَ مِنْ حَقِّ وَإِنَّكَ لَتَعْلَمُ مَا نُرِيدُ }
$$

Terjemahnya:

"Mereka menjawab: 'Sesungguhnya kamu telah tahu bahwa Kami tidak mempunyai keinginan terhadap puteri-puterimu; dan Sesungguhnya kamu tentu mengetahui apa yang sebenarnya Kami kehendaki,"’

Ayat di atas menggambarkan keadaan kaum Nabi Luth yang menjadikan perilaku sodom sebagai budaya dan kebiasaan mereka sejak dahulu dan kemudian dilestarikan oleh orang-orang yang datang setelahnya. Ini terlihat dari perkataan kaum Sodom ketika menjawab tawaran Nabi Luth untuk menikahi putri-putri beliau pada ayat sebelumnya. Jawaban mereka tentang mengetahuinya Nabi Luth atas keinginan mereka menunjukkan bahwa perilaku seksual sesama jenis merupakan hal yang lumrah diketahui oleh masyarakatnya ${ }^{47}$. Oleh karena dampaknya yang begitu besar bagi kehidupan sosial, maka Allah langsung menghukum kaum tersebut dengan menghujani batu-batu hingga kaum tersebut musnah. Ini merupakan kesudahan bagi kaum yang telah melanggar fitrah manusia $^{48}$.

Telah diketahui bahwa fitrah manusia dalam hubungan seksual adalah kepada lawan jenis. Ketika fitrah tersebut dilanggar, maka dampak yang besar akan muncul ${ }^{49}$. Dampak tersebut dapat berupa ketidaktentraman dalam kehidupan masyarakat karena perilaku tersebut dapat menular, kekerasan, mewabahnya penyakit AIDS, terancamnya hak warga untuk mendapatkan suasana yang sehat dan bebas dari pelanggaran seksual, dan terhambatnya jumlah kelahiran serta rusaknya nilai-nilai baik di masyarakat ${ }^{50}$. Karakter lainnya yang ditemukan dalam Al-Qur'an adalah berbuat curang yang merupakan representasi

\footnotetext{
${ }^{46}$ Fatwa Majelis Ulama Indonesia, no.3 tahun 2004 tentang Terorisme.

${ }^{47}$ M. Quraish Shihab, Tafsìr al-Miṣbāḥ; Pesan, Kesan dan Keserasian Al-Qur'an, (Jakarta: Lentera Hati, 2002), vol 5, h. 702.

${ }^{48}$ M. Quraish Shihab, Tafsìr al-Miṣbāḥ; Pesan, Kesan dan Keserasian Al-Qur'an, (Jakarta: Lentera Hati, 2002), vol 5, h. 706.

${ }^{49}$ M. Quraish Shihab, M. Quraish Shihab Menjawab; 1001 Soal Keislaman yang Patut Anda Ketahui (Jakarta: Lentera Hati, 2008), h. 485-487.

${ }^{50}$ Ihsan Dacholfany, "Dampak LGBT dan Antisipasinya di Masyarakat", Nizham 5(1), (2016): h. 110-111.
} 
dari karakter feminin negatif. Sebagaimana yang telah dijelaskan dalam AlQur'an dalam surah al-A'raf ayat 85. Ayat tersebut menyatakan bahwa Nabi Syu'aib yang merupakan nabi yang diutus pada kaum Madyan memperingatkan kaumnya agar tidak melakukan kerusakan di bumi dengan tindakan mereka yang tidak memenuhi hak orang lain dengan mengurangi takaran yang seharusnya. Tindakan ini pun dipertegas kecamannya di ayat lain yaitu pada surah alMuțaffifīn/83: 1-3 yang berbunyi:

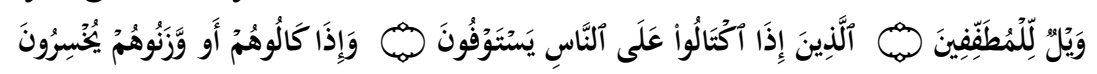

Terjemahnya:

"Kecelakaan besarlah bagi orang-orang yang curang (1), (yaitu) orangorang yang apabila menerima takaran dari orang lain mereka minta dipenuhi (2), dan apabila mereka menakar atau menimbang untuk orang lain, mereka mengurangi (3)".

Ayat di atas menjelaskan mengenai ancaman bagi orang yang melakukan kecurangan dalam perdagangan. Kecurangan di sini terdiri dari dua hal seperti yang tertera pada ayat 2 dan 3 , yaitu orang yang menerima takaran dan menuntut kelebihan dan yang mengurangi timbangan atau takaran dalam bertransaksi. Perilaku seperti ini menurut Quraish Shihab tidak hanya berbuat curang, akan tetapi merupakan tindakan pencurian bahkan pelecehan. Disebut dengan pelecehan karena pelaku tersebut telah berani melakukan kecurangan itu dengan menganggap remeh mitranya,${ }^{51}$ karena dalam kehidupan bermuamalah dituntut untuk saling menghormati, menjaga hak orang lain, dan menjaga hubungan baik dengan sesama mitra, serta perlu menjaga ketentraman sesama ${ }^{52}$.

Contoh-contoh di atas memberikan gambaran besar bahwa karakter negatif mengakibatkan dampak buruk bagi kehidupan sosial. Ini juga menunjukkan bahwa perlu ada keseimbangan antara karakter maskulin dan feminin yang positif. Oleh karena itu, jika keduanya tidak seimbang, maka jati diri manusia yang merepresentasikan khalifah di muka bumi menjadi hal yang sulit dicapai. Terlebih jika karakter negatif tersebut justru yang mendominasi dalam diri manusia, maka dampak yang timbul menjadi lebih besar lagi.

\section{KESIMPULAN}

Topik mengenai maskulinitas dan femininitas berada dalam dua kerangka keilmuan, baik ada dalam kerangka keilmuan barat maupun Islam. Keduanya memiliki perdebatan tertentu yang masing masing memiliki persamaan dan perbedaan. Benang merah dari keduanya yaitu terdapat pandangan yang

${ }^{51}$ M. Quraish Shihab, Tafsìr al-Miṣbāḥ; Pesan, Kesan dan Keserasian Al-Qur'an, (Jakarta: Lentera Hati, 2002), vol 15, h. 123.

52 Rusydi AM, "Perdagangan dalam Perspektif Al-Qur'an," Disertasi Program Pascasarjana UIN Syarif Hidayatullah, 2001, h. 193-194. 
menekankan perbedaan antara karakter maskulin dan feminin berdasarkan aspek biologis. Pandangan tersebut tentu banyak ditolak oleh kaum intelektual yang memiliki argumen bahwa peran dan karakter laki-laki dan perempuan tidak bisa dilihat dari aspek biologis, akan tetapi dilihat dari sosial budaya di mana mereka tinggal.

Pandangan kaum intelektual yang membedakan karakter maskulin dan feminin berdasarkan dari aspek biologis pada ujungnya akan menepatkan karakter maskulin sebagai karakter yang lebih unggul dari karakter feminin. Akan tetapi, dalam tulisan ini merujuk kepada teori Murata yang memposisikan pada pandangan bahwa baik karakter maskulin dan feminin memiliki sisi positif maupun negatif dan kedua karakter tersebut terdapat dalam diri setiap individu.

Berkaitan dengan karakter maskulin dan feminin negatif yang menjadi persoalan dan analisis penulis, ditemukan bahwa karakter negatif tersebut memiliki implikasi atau dampak yang buruk terhadap aspek sosial dalam perspektif Al-Qur'an. Karakter-karakter tersebut di antaranya; (1) sifat sombong yang diwakili oleh Fir'aun dan Qarun sebagai representasi maskulin negatif, (2) menyerah kepada hawa nafsu yang dicontohkan oleh Qabil dan kaum Sodom sebagai representasi dari karakter feminin negatif, (3) berbuat curang dalam takaran yang termasuk dalam kategori feminin negatif dan karakter ini direpresentasikan oleh kaum Madyan.

\section{DAFTAR PUSTAKA}

Al-Qur'ān al-Karīm..

AM, Rusydi. (2001). Perdagangan dalam Perspektif Al-Qur'an, (Disertasi Program Pascasarjana UIN Syarif Hidayatullah).

Al-Baghawī. (1990). Tafs̄̄r al-Baghaw̄̄; Ma'ālim al-Tanzīl, jilid 6. Riyadh: Dār Țayyibah.

Al-Baiḍāwī. Anwār al-Tanz̄̄l wa Asrār al-Ta’wōl, jilid 4. Dār Ihyyā al-Turāth al'Arabī.

Al-Zamakhsyari. (2009). Tafs̄ì al-Kasysyā ' 'an Haqāiq al-Tanz̄l wa 'Uyūn li alAqā w̄̄l fi Wujūh al-Ta'w̄̄l(Vol.5). Beirut: Dār al-Ma'rifah.

Al-Zuhaili, Wahbah. (1998). al-Tafsìr al-Munìr fi al- 'aqìdah al-Syan̄'ah wa alManhāj. Beirut: Dār al-Fikr al-Mu'āșir.

Andika, Mayola. (2018). Reinterpretasi Ayat Gender dalam Memahami Relasi Laki-laki dan Perempuan (Sebuah Kajian Kontekstual dalam Penafsiran. Musawa, 17(2), 142.

Bem, Sandra L. (1974). The Measurement of Psychological Androgyny. Journal of Consulting and Clinical Psychology, 42(2). 
Ciciek, Farha. (1999). Ikhtiar dalam Mengatasi Kekerasan dalam Rumah Tangga; Belajar dari Kehidupan Rasulullah saw. Jakarta: Lembaga Kajian Agama dan Gender.

Dacholfany, Ihsan. (2016). Dampak LGBT dan Antisipasinya di Masyarakat. Nizham 5(1), 110-111.

Febriani, Nur Arfiyah. (2014). Ekologi Berwawasan Gender dalam Perspektif AlQur'an. Bandung: Mizan Pustaka.

Fatwa Majelis Ulama Indonesia, no.3 tahun 2004 tentang Terorisme.

Frosh, Stephen. (2002). Sexual Difference: Masculinity and Psychoanalysis. New York: Taylor \& Francis e-Library.

Hawwā, Sa'īd. (1999). al-Asās fì al-Tafsìr. Mesir: Dār al-Salām.

Hasyim, Syafiq. Ed. (1999). Menakar "Harga" Perempuan; Eksplorasi Lanjut atas Hak-hak Reproduksi Perempuan. Bandung: Mizan.

Heilbrun, Afred B. Jr. (1976). Measurement of Masculine and Feminine Sex Role Identities as Independent Dimension. Journal of Consulting and Clinical Psychology, 44(2), 183.

Hoffman, Rose Marie. (2001). Measurement of Masculiniy and Femininity: Historical Perpective and Implication for Counseling. Journal of Counseling and Development, 79, 472-476.

Howell, Nancy R. (1997). Ecofeminism: What One Needs to Know. Zygon, 32(2), 231-232.

Ibn Kas̄īr. (1999). Tafs̄ir al-Qur'ān al- 'Adhīm, jilid 3. Riyadh: Dār Ṭayyibah li alNaṣr wa al-Tauzi'.

Jejen, Musfah. (2007). Indeks Al-Qur'an Praktis. Jakarta: Hikmah.

Jeglińska., Herman, Anna., Grabowska, Anna., \& Dulko, Stanislaw. (2002).

Masculinity , Femininity, and Transsexualism. Archives of Sexsual Behavior, 3(6), 529.

Kirkland, Russell. (2002). The History of Taoism: A New Outline. Journal of Chinese Religion, 30(1), 180.

Morawski, J G. (1985). The Measurement of Masculinity and Femininity: Engendering Categorical Realities. Durham: Duke University.

Muhanna, Aitemahad. (2015). Agency and Gender in Gaza: Masculinity and Family during the Second Intifada. Gender \& History, 27(1), 234.

Mulia, Siti Musdah \& Anwar, Marzani. Ed. (2001). Keadilan dan Kesetaraan Jender Perpektif Islam. Tim Pemberdayaan Perempuan Bidang Agama Departemen Agama RI.

Murata, Sachiko. (1992). The Tao of Islam; A Sourcebook on Gender Relationship in Islamic Thought. (Rahmani Astuti dan M.S Nasrullah). Bandung: Mizan. 
Muṭahhari, Murtaḍa. (2012). Filsafat Perempuan dalam Islam. (Arif Mulyadi). Yogyakarta: Rausyanfikr Institute.

Orlofsky, Jacob L. \& Stake, Jayne E. (1981). Psychological Masculinity and Femininity: Relationship to Striving and Self-Concept in The Achievemen and Interpersonal Domains, Psychology of Women Quarterly, 6, 218.

Palan, Kay M., Areni, Charles S., \& Kiecker, Pamela. (1999). Reexamining Masculinity, Femininity, and Gender Identity Scales, Marketing Letters, 10(4), 365.

Paechter, Carrie. Masculine Femininities/Feminine Masculinities: Power, Identities and Gender. Gender Education.

Al-Rāzī. Mafàtīh al-Gā̄b(Vol. 10). Beirut: Dār al-Fikr.

Shihab, M. Quraish. (2002). Tafsīr al-Miṣbāḥ; Pesan, Kesan dan Keserasian AlQur'an (Vol. 3). Jakarta: Lentera Hati.

. (2002). Tafsìr al-Miṣbāh; Pesan, Kesan dan Keserasian AlQur'an (Vol. 10). Jakarta: Lentera Hati.

. (2002). Tafsìr al-Miṣbāh; Pesan, Kesan dan Keserasian AlQur'an (Vol. 15). Jakarta: Lentera Hati.

Siddique, Kaukab. (2002). Menggugat “Tuhan yang Maskulin”. (Arif Maftuhin). Jakarta: Paramadina.

Spence, Janet T., Helmreich, Robert L., \& Holahan, Carole K. (1979).Negative and Positive Components of Psychological Masculinity and Femininity and Their Relationships to Self-Reports of Neurotic and Acting Out Behaviors. Journal of Personality and Social Psychology, 37(10).

Spence, Janet T., Helmreich, Robert L., \& Stapp, Joy. (1975). Rating of Self and Peers on Sex Role Attributes and Their Relation to Self-Esteem and Conceptions of Masculinity and Femininity. Journal of Personality and Sosial Psychology, 32(1), 29.

Suryorini, Ariana. (2012). Menelaah Feminisme dalam Islam. Sawwa, 7(2).

Umar, Nasaruddin. (1999). Kodrat Perempuan dalam Islam. Jakarta: Lembaga Kajian Agama dan Gender.

Weber, Max. (1951). The Religion of China; Confucianism and Taoism. Illinois: The Free Press.

Yang, Yingying \& Merrill, Edward C. Cognitive and Pesonality Characteristics of Masculinity and Femininity Predict Wayfinding Competence and Strategies of Men and Woman. Sex Roles. 